\title{
The STAD Model Assisted by Audio Visual Media Increases Student Motivation and Learning Achievement
}

\author{
Dian Istiqorini Setiaruf \\ Fakultas Ilmu Pendidikan, Universitas PGRI Semarang, Semarang, Indonesia \\ *Corresponding author: istiqorinisetiaruf@gmail.com ${ }^{1}$
}

\begin{abstract}
Abstrak
Rendahnya motivasi belajar peserta didik pada proses pembelajaran. Motivasi awal peserta didik 69\% (kurang) yaitu dari 14 peserta didik hanya 4 peserta didik yang memenuhi indikator keberhasilan. Hal ini disebabkan guru masih mendominasi kegiatan belajar mengajar sehingga pembelajaran berpusat pada guru. Pada proses pembelajaran, beberapa peserta didik tidak memperhatikan pelajaran yang diberikan oleh guru. Penelitian ini bertujuan untuk mengetahui peningkatan motivas dan prestasii belajar peserta didik melalui model kooperatif tipe Student Teams Achievement Divisions berbantuan media audio visual. Jenis penelitian ini adalah penelitian tindakan kelas. Prosedur penelitian dilaksanakan dalam dua siklus. Sumber data yang diambil yaitu seluruh kelas $V$ yang berjumlah 14 peserta didik. Metode pengumpulan data yang digunakan adalah dokumentasi, angket, dan wawancara. Teknik analisis data yang digunakan adalah analisis kuantitatif dan deskriptif kualitatif. Hasil penelitian menunjukkan adanya peningkatan motivasi peserta didik. Motivasi belajar peserta didik pada siklus I mencapai 74\% (cukup) sebanyak 8 peserta didik telah memenuhi indikator keberhasilan dan pada siklus II menjadi $81 \%$ (baik) sebanyak 12 peserta didik telah memenuhi indikator keberhasilan. Berdasarkan hasil analisis dan pembahasan tersebut dapat disimpulkan bahwa model kooperatif tipe Student Teams Achievement Divisions dapat meningkatkan motivasi dan prestasi belajar siswa.
\end{abstract}

Kata kunci: Motivasi, STAD, audio visual

\section{Abstract}

The low learning motivation of students in the learning process. The initial motivation of students is $69 \%$ (less), namely out of 14 students, only four students meet the indicators of success. It is because teachers still dominate teaching and learning activities so that learning is teacher-centered. In the learning process, some students did not pay attention to the lessons given by the teacher. This study aims to determine the increase in motivation and learning achievement of students through the cooperative model of the Student Teams Achievement Divisions type assisted by audio-visual media. This type of research is classroom action research. The research procedure was carried out in two cycles. The source of the data taken is the entire class V, totaling 14 students. Data collection methods used are documentation, questionnaires, and interviews. The data analysis technique used is quantitative and descriptive qualitative analysis. The results showed an increase in student motivation. Students' learning motivation in the first cycle reached $74 \%$ (enough) as many as 8 students had met the success indicators, and in the second cycle, it was $81 \%$ (good) as many as 12 students had met the success indicators. Based on the results of the analysis and discussion, it can be concluded that the Student Teams Achievement Divisions type cooperative model can increase students' motivation and learning achievement.

Keywords: Motivation, STAD, audio visual

\begin{tabular}{lll}
\hline History: & & Publisher: Undiksha Press \\
Received & : December 21,2020 & Licensed: This work is licensed under \\
Revised & : January 21,2021 & a Creative Commons Attribution 3.0 License \\
Accepted & : June 10,2021 & CC () () \\
Published & : July 25, 2021 & SA
\end{tabular}

\section{Introduction}

Science is constantly developing and progressing according to the times and the development of human thinking (Huang et al., 2020; Montoya et al., 2021). The nation's quality of life can improve if an established education supports it. A good education will enable a person to develop critical, creative, and productive thinking skills (Hussin, 2018; Muhtar \& Dallyono, 2020; Stone et al., 2013). The curriculum is critical in learning. The curriculum must pay attention to several essential things, including the development of students, advances in science and technology, and the needs in society (Chien, 2017; Polizzi, 2020; Thoyyibah et al., 2019). 
Since implementing the 2013 curriculum, all learning has been taught thematically using an integrated scientific and thematic approach (Kurniasari, 2017; Mega et al., 2015). The 2013 curriculum aims to prepare Indonesian people to have the ability to live as individuals and citizens who are faithful, productive, creative, innovative, and practical and able to contribute to the life of society, nation, state, and world civilization (Sutrisno et al., 2021; Wulandari, 2020). Learning in the 2013 Elementary School Curriculum is studentcentered. Students are the center of learning, while the teacher acts more as a facilitator who facilitates students to carry out learning activities (Montoya et al., 2021; Selvianiresa \& Prabawanto, 2017).

The researcher made observations in the fifth grade of SD N Luwung 02, implementing the 2013 curriculum. The problem from the observations was the motivation of students in the learning process. The students' learning motivation is $71 \%$ (enough). That is, out of 14 students, only four students meet the indicators of success. The 2013 curriculum requires students to be active in the learning process. However, what happened in the classroom was that only a few students were active. In the learning process, some students do not pay attention to the lessons given by the teacher and do not take the lessons seriously. When working in groups, only a few students participate in doing the assignments, while other students do not participate in doing the assignments. They only rely on intelligent students. It is because the motivation of students to participate in learning activities is still low.

Motivation is essential in learning activities because someone who does not have motivation in learning will not be able to carry out learning activities (Rahmat \& Akbar, 2019; Saito et al., 2018). Motivation is a psychological symptom in the form of an impulse that arises in a person consciously or unconsciously to take any action with a specific purpose (Abdelrahman, 2020; Leona et al., 2021). A person performs a learning activity because someone is pushing it. Motivation is the driving force that drives a person to learn (Guswara, 2020; Veselova et al., 2021). The success of learning is determined by learning outcomes and is also determined by the learning process. In the learning process, the teacher can assess students' motivation towards the subject matter provided by the teacher (Ardhaoui et al., 2021; Parker et al., 2021). Students' interest in learning depends on the motivation of students to study the subject matter (Abdelrahman, 2020; Sumantri \& Whardani, 2017).

The solution offered to overcome these problems is by using innovative learning models that can increase student motivation in learning (Aprilianingrum \& Wardani, 2021; Fadli et al., 2020). One of the innovative learning models that teachers can use is the Student Teams Achievement Divisions type cooperative learning model. The cooperative learning model is a series of learning activities carried out by students in specific groups to achieve learning objectives (Nurhusain, 2017; Qusyairi \& Sakila, 2018). Implementing the cooperative learning model will show learning activities to be effective (Dupri et al., 2020; Monica et al., 2017). In the cooperative learning model, there are five elements, namely: positive interdependence, individual responsibility, face to face, communication between members, and evaluation of group processes (Alfiani \& Sopiyani, 2014; Diartini \& Ratnawuri, 2017). Learning activities emphasize positive interdependence between individual students, individual responsibility, face-to-face, intensive communication between students, and evaluation of group processes (Nugraha et al., 2016; Rabgay, 2018).

One type of cooperative learning is the Student Teams Achievement Divisions model. The Student Teams Achievement Divisions model can motivate students to support each other and help group members in mastering the abilities taught by the teacher (Anjani, 2017; Wardani, 2015). If students want their team to get team awards, then students must teach their group members and at the same time learn the material for themselves (Alman, 2017; Zahro et al., 2018). In cooperative learning, students learn to help each other master teaching materials and increase interaction between students (Anggraini et al., 2018; Widowati, 2011). 
Students in groups will learn to hear other people's ideas, discuss agree or disagree, offer or accept constructive criticism.

In addition to innovative learning models, other factors that support successful learning are learning media (Heo \& Toomey, 2020; Purwanita et al., 2019). The use of learning media can make it easier for teachers to convey information so that it will increase students' understanding of learning (Manurung \& Panggabean, 2020; Rubini et al., 2018). Media is anything that can channel messages from people who give messages to people who receive good messages (Price et al., 2017; Ran et al., 2016). One of the learning media that can facilitate student learning is audio-visual media. Audio-visual media, namely media which is a combination of audio and visual or commonly called viewing-hearing media. Audio-visual media is media that can display images and sound elements. The combination of these two elements makes audio-visual media have better capabilities. This learning media can facilitate student learning styles so that it is seen as making it easier for students to learn.

Previous research stated that audio-visual media could make it easier for students to understand learning materials (Fauzi et al., 2017; Michelsanti et al., 2019; Setiawan \& Ari Oka, 2020). The findings of previous studies also stated that cooperative learning could increase students' enthusiasm and motivation to learn (Dupri et al., 2020; Gjems, 2013; Nurhusain, 2017). It can be concluded that cooperative learning with the aid of media will facilitate students in learning. There is no study on the Student Teams Achievement Divisions model with the aid of audio-visual media. The purpose of this study is to analyze the STAD model assisted by audio-visual media. The STAD model assisted by audio-visual media is expected to increase students' motivation and learning achievement.

\section{Methods}

This type of research is classroom action research. This research was conducted at SD $\mathrm{N}$ Luwung 02. This study took fifth-grade students as the object of research. The subjects of this study were the fifth-grade students of SD N Luwung 02, with 14 students consisting of 8 female students and six male students. The data used in this study are qualitative and quantitative. Qualitative data describes the process and learning outcomes obtained through observation in words and actions, written data sources, and photos. Quantitative data is statistical data in the form of numbers such as the average results from questionnaires and quiz scores in each cycle which gives an idea of the tendency to increase or decrease learning motivation.

Data collection techniques are methods that researchers can use to collect data. Data collection techniques used in the research are documentation, questionnaires, and interviews. Documentation in this study is in the form of field note data, a written record of everything that happens during the learning process in class. This study uses a questionnaire in the form of a learning motivation questionnaire consisting of statements that students will fill out to measure learning motivation. Indicators of learning motivation include (a) persevering in facing tasks, (b) being tenacious in facing difficulties, (c) showing interest in various problems, (d) preferring to work independently, (e) getting bored quickly on routine tasks, (f) ) can defend his opinion, (g) it is not easy to let go of what he believes in, and (h) Happy to find and solve problems. The technique used to analyze the data is descriptive qualitative and quantitative analysis. The score in this research instrument consists of a range of 4-1, namely the statements of good SL (4), SR (3), KD (2), and TP (1). Unfavorable statements TP (1), KD (2), SR (3), and SL (4). 


\section{Results and Discussion Results}

The data obtained when making observations in class $\mathrm{V}$ is students' low motivation and achievement in the learning process. Students' learning motivation is $69 \%$ (enough). That is, out of 14 students, only four students meet the indicators of success. The 2013 curriculum requires students to be active in the learning process, but what happens in the classroom is that only a few students are active. In the learning process, some students do not pay attention to the lessons given by the teacher and do not take the lessons seriously. When working in groups, only a few students participate in doing the assignments, while other students do not participate in doing the assignments. Students only rely on smart students. It is because the motivation of students to participate in learning activities is still low.

Activities carried out in this pre-cycle include conducting interviews with fifth-grade teachers about the motivation and methods used by teachers. To find out the initial data on motivation, a questionnaire was given to students. Data from the results of filling out a questionnaire about students' motivation before the action, namely the achievement of students' learning motivation in the first cycle on the indicator of diligently facing the task, reached $73 \%$ included in the excellent category. The tenacity indicator facing difficulties reaches $73 \%$, which is included in the excellent category. The indicator shows interest in various problems reaching 66\%, which is included in the excellent category. Fast indicators prefer to work independently, reaching $73 \%$ included in the excellent category. Indicators of getting bored quickly on routine tasks $63 \%$ are included in the excellent category. The indicator can maintain its opinion reaching $63 \%$, which is included in the excellent category. It is not easy to let go of what is believed to reach $70 \%$, which is included in the excellent category. The indicator of happy to find and solve problems the questions reach $75 \%$ is included in the excellent category.

Cycle 1 was carried out in two meetings which were carried out according to the thematic lesson schedule at the school. The first meeting was held with a time allocation of 7 x 35 minutes. The Student Teams Achievement Divisions learning model was implemented in the first cycle in two meetings. The implementation procedure is as follows. At the first meeting of the first cycle of learning Theme 2 Clean Air for Health, Sub-theme Importance of Clean Air for Breathing, learning 1. Learning activities refer to the Lesson Plan (RPP) that has been prepared. The assessment of the success of the actions in the first cycle was carried out by giving the first cycle questionnaires to the students. In the first cycle of action, there was an increase in each indicator. The results of the student learning motivation questionnaire in cycle I can be seen in Table 1.

Table 1. Analysis of Learning Motivation Questionnaire Results Cycle I

\begin{tabular}{llcc}
\hline No & \multicolumn{1}{c}{ Indicator } & Percentage & Category \\
\hline 1 & Persevere in the face of the task & $79 \%$ & Good \\
2 & Tenacious in the face of adversity & $76 \%$ & Good \\
3 & Shows interest in various issues & $69 \%$ & Enough \\
4 & Prefer to work independently & $80 \%$ & Good \\
5 & Get bored quickly on routine tasks & $70 \%$ & Enough \\
6 & Can defend his opinion & $70 \%$ & Enough \\
7 & It's not easy to let go of what you believe in & $75 \%$ & Enough \\
8 & Enjoy finding and solving problems & $77 \%$ & Good \\
& $\quad$ Average & $74 \%$ & Good \\
\hline
\end{tabular}


Based on the data in the table above, it can be seen that the achievement of students' learning motivation in the first cycle on the indicator of being diligent in facing the task reached $79 \%$, which was included in the excellent category. The tenacity indicator facing difficulties reaches $76 \%$, which is included in the good category. The indicator shows interest in various problems reaching 69\%, which is included in the excellent category. Fast indicators prefer to work independently, reaching $80 \%$ included in the excellent category. Indicators of getting bored quickly on routine tasks $70 \%$ are included in the good category. The indicator can maintain its opinion reaching $70 \%$, which is included in the good category. It is not easy to let go of what is believed to reach $75 \%$, which is included in the good category. The indicator of happy to find and solve problems the questions reached $77 \%$ included in the good category. The average learning motivation of students in the first cycle reached $74 \%$, which was included in the good category.

Cycle II was carried out in two meetings which were carried out according to the thematic lesson schedule at the school. The first meeting was held with a time allocation of 7 x 35 minutes. The Student Teams Achievement Divisions learning model was implemented in the first cycle in two meetings. The implementation procedure is as follows. At the 1st meeting of the first cycle, it was carried out with learning Theme 3 Clean Air for Health, Sub-theme of Maintaining the Health of Human Respiratory Organs, learning 2. Learning activities refer to the Learning Implementation Plan (RPP) that has been prepared. The second meeting of the second cycle was carried out by learning Theme 3, Clean Air for Health, Sub-theme of Maintaining the Health of Human Respiratory Organs, learning 3. Learning activities refer to the Learning Implementation Plan (RPP) that has been prepared.

The assessment of the success of the actions in the second cycle is carried out by giving the second cycle questionnaires to the students. In the second cycle of action, there was an increase in each indicator. The results of the student learning motivation questionnaire in cycle II can be seen in Table 2.

Table 2. Analysis of the Results of the Cycle II Learning Motivation Questionnaire

\begin{tabular}{clcc}
\hline No & \multicolumn{1}{c}{ Indicator } & Percentage & Category \\
\hline 1 & Persevere in the face of the task & $83 \%$ & Good \\
2 & Tenacious in the face of adversity & $78 \%$ & Good \\
3 & Shows interest in various issues & $80 \%$ & Good \\
4 & Prefer to work independently & $83 \%$ & Good \\
5 & Get bored quickly on routine tasks & $80 \%$ & Good \\
6 & Can defend his opinion & $80 \%$ & Good \\
7 & It's not easy to let go of what you believe in & $82 \%$ & Good \\
8 & Enjoy finding and solving problems & $82 \%$ & Good \\
& $\quad$ Average & $81 \%$ & Good \\
\hline
\end{tabular}

Based on the table data above, it can be seen that the achievement of students' learning motivation in cycle II on the indicators of being diligent in facing the task reaches $83 \%$, including in the excellent category. The tenacity indicator facing difficulties reaches $78 \%$, which is included in the excellent category. Indicators showing interest in various problems reached $80 \%$ included in the excellent category. Fast indicators prefer to work independently, reaching 83\% included in the excellent category. Indicators of getting bored quickly on routine tasks $80 \%$ are included in the excellent category. The indicator can maintain its opinion reaching $80 \%$, which is included in the excellent category. It is not easy to let go of what is believed to reach $82 \%$, which is included in the excellent category. The indicator of happy to find and solve problems the questions reached $82 \%$ included in the 
excellent category. The average learning motivation of students in the second cycle reached $81 \%$, including in the excellent category.

\section{Discussion}

The researcher and the teacher carried out the reflection in cycle II to conduct an assessment during the learning process using the Student Teams Achievement Divisions type cooperative model. Based on the discussion, it is known that the implementation of learning using the cooperative model of the Student Teams Achievement Divisions type has been running according to the design prepared previously. It can be concluded that the cooperative model is effectively used in learning (Fu et al., 2012; Khan \& Masood, 2015). This learning model makes students work together in small groups consisting of various levels of achievement, gender, and ethnic backgrounds to help each other learn the subject matter (Afinda et al., 2019; Foldnes, 2016; Liebech-Lien, 2021). It allows students to help each other, discuss and argue with each other to hone their current knowledge and close the gaps in their understanding (Haryono, 2020; Ruengtam, 2013; Stone et al., 2013).

In addition, the use of learning media during the learning process is also very helpful in improving the learning atmosphere (Alfiah et al., 2018; Fauzi et al., 2017). One of the developments in education is the creation of more varied and exciting learning media, thus making the learning atmosphere more conducive and focused (Amali et al., 2020; Indrianto \& Kurniawati, 2020). The primary function of learning media is to realize more effective learning (Boyd, 2019; Ismara et al., 2021). It will affect the quality of better learning outcomes if the use of the media is appropriate. The audiovisual media used can improve students' understanding of learning (Michelsanti et al., 2019; Setiawan \& Ari Oka, 2020). Audiovisual media is a combination of audio and visual media to complete the presentation of learning materials (Kkese, 2020; Virgiana \& Wasitohadi, 2016). Audiovisual media is a tool used to help written and spoken words convey knowledge, attitudes, and ideas in learning (Michelsanti et al., 2019; Xu \& Wu, 2021). The audiovisual media used are images, videos, and sounds to make it easier for students to receive learning materials (Anjarsari et al., 2020; Larue \& Watling, 2021). Thus, audiovisual media enrich the learning environment, nurture exploration, experimentation, and discovery, and encourage students to develop speech and express their thoughts (Wang et al., 2020; Widiatmika et al., 2017).

The findings of previous studies also stated that audio-visual media could increase student motivation, so it impacts student learning outcomes (Michelsanti et al., 2019; Pattemore \& Muñoz, 2020; Xu \& Wu, 2021). Other research findings also state that the STAD type cooperative learning model creates a pleasant learning atmosphere to improve student learning outcomes (Alfiani \& Sopiyani, 2014; Laksono et al., 2016; Widowati, 2011). It can be concluded that the STAD type cooperative learning model with audio-visual media can help students learn. This research implies that teachers in the learning process can apply the STAD type cooperative learning model with audio-visual media to increase students' motivation and learning achievement.

\section{Conclusion}

The achievement of students' learning motivation in cycle I to Cycle II with the cooperative model of the Student Teams Achievement Divisions type increased. It can be concluded that the application of the Student Teams Achievement Divisions type cooperative model with the aid of audio-visual media can increase students' motivation and learning achievement. 


\section{References}

Abdelrahman, R. M. (2020). Metacognitive awareness and academic motivation and their impact on academic achievement of Ajman University students. Heliyon, 6(9). https://doi.org/10.1016/j.heliyon.2020.e04192

Afinda, Aisyah, \& Wijayanti. (2019). Cooperative-STAD Dengan Word Square: Dampaknya Terhadap Motivasi Dan Hasil Belajar Siswa. JIPVA (Jurnal Pendidikan Ipa Veteran), 3(1), 17 - 27. https://doi.org/10.31331/jipva.v3i1.773

Alfiah, A. N., Putra, N. M. D., \& Subali, B. (2018). Media Scrapbook Sebagai Jurnal Refleksi untuk Meningkatkan Kemampuan Kognitif dan Regulasi Diri. Jurnal Pendidikan (Teori Dan Praktik), 3(1), 57. https://doi.org/10.26740/jp.v3n1.p57-67

Alfiani, D. A., \& Sopiyani, S. (2014). Pengaruh Model Pembelajaran Cooperative Learning Tipe (STAD) Student Teams Achievement Division terhadap Hasil Belajar IPA Siswa Kelas V di SD Negeri 1 Tersana Kecamatan Pabedilan Kabupaten Cirebon. Al Ibtida: Journal Pendidikan Guru MI, 1(1). https://doi.org/10.24235/al.ibtida.snj.v1i1.459

Alman. (2017). The Influence of Open-Ended and STAD Method on the Mathematical Problem-Solving Skills in Terms of Learning Achievement. Jurnal Prima Edukasia, 5(2), 112-124. https://doi.org/10.21831/jpe.v5i2.14280

Amali, L. N., Zees, N., \& Suhada, S. (2020). Motion Graphic Animation Video As Alternative Learning Media. Jambura Journal of Informatics, 2(1). https://doi.org/10.37905/jji.v2i1.4640

Anggraini, D., Relmasira, S., \& Tyas Asri Hardini, A. (2018). Penerapan Model Pembelajaran Student Teams Achievement Division (Stad) Melalui Media Pembelajaran Ular Tangga Untuk Meningkatkan Kemampuan Berpikir Kritis Dan Hasil Belajar Ips Pada Peserta Didik Kelas 2 Sd. Pendekar: Jurnal Pendidikan Berkarakter, 1(1), 324. https://doi.org/10.31764/pendekar.v1i1.379

Anjani, S. (2017). Model Pembelajaran Student Teams Achievement Divisions Berbasis Tri Hita Karana Berpengaruh Terhadap Kompetensi Pengetahuan IPA. Mimbar PGSD Undiksha, 5, 1-11. https://doi.org/10.23887/jjpgsd.v5i2.10794

Anjarsari, E., Donny, D. F., \& Abdul, W. A. (2020). Pengembangan Media Audiovisual Powtoon pada Pembelajaran Matematika untuk Siswa Sekolah Dasar. Jurnal $\begin{array}{llll}\text { Matematika Dan Pendidikan } & \text { Matematika, }\end{array}$ https://doi.org/10.26594/jmpm.v5i2.2084

Aprilianingrum, D., \& Wardani, K. W. (2021). Meta Analisis: Komparasi Pengaruh Model Pembelajaran Problem Based Learning dan Discovery Learning dalam Meningkatkan Kemampuan Berpikir Kritis Siswa SD. Jurnal Basicedu, 5(2), 1006-1017. https://doi.org/10.31004/basicedu.v5i2.871

Ardhaoui, K., Lemos, M. S., \& Silva, S. (2021). Effects of new teaching approaches on motivation and achievement in higher education applied chemistry courses: A case study in Tunisia. Education for Chemical Engineers, 36. https://doi.org/10.1016/j.ece.2021.05.004

Boyd, L. (2019). Using Technology-Enabled Learning Networks to Drive Module Improvements in the UK OpenUniversity. Journal of Interactive Media in Education, 2019(1), 1-7. https://doi.org/10.5334/jime.529

Chien, Y. H. (2017). Developing a pre-engineering curriculum for 3D printing skills for high school technology education. Eurasia Journal of Mathematics, Science and Technology Education, 13(7), 2941-2958. https://doi.org/10.12973/eurasia.2017.00729a

Diartini, R., \& Ratnawuri, T. (2017). Penggunaan Model Cooperative Learning Tipe Probing Prompting Berbantu Media Flash Card Terhadap Hasil Belajarips Terpadu. PROMOSI (Jurnal Pendidikan Ekonomi), 5(1), 57-63. https://doi.org/10.24127/ja.v5i1.846

Dupri, D., Candra, O., Candra, A., \& Suryani, D. A. (2020). The Implementation of Problem 
Based Learning Model in Improving Cooperation and Learning Outcomes in Physical Education. Jurnal Pendidikan Jasmani Dan Olahraga, 5(1). https://doi.org/10.17509/jpjo.v5i1.22531

Fadli, M. R., Sudrajat, A., Zulkarnain, A., Setiawan, R., \& Amboro, K. (2020). The Effectiveness of E-Module Learning History Inquiry Model to Grow Student Historical Thinking Skills Material Event Proclamation of Independence. Decision Making, 6(7). http://sersc.org/journals/index.php/IJAST/article/view/20146

Fauzi, H. A., Komalasari, K., \& Malik, Y. (2017). Utilization of Audio Visual Media to Improve Student Learning Result in IPS Learning. International Journal Pedagogy of Social Studies, 2(1), 88-103. https://doi.org/10.17509/ijposs.v2i1.8666

Foldnes, N. (2016). The flipped classroom and cooperative learning: Evidence from a $\begin{array}{llll}\text { randomised } & \text { experiment. }\end{array}$ https://doi.org/10.1177\%2F1469787415616726

Fu, B., Zhang, P., \& Wang, C. (2012). A Cooperation Strategy for Shooting in Robot Soccer Competition Based on the Multi-Suppose Tree. Procedia Engineering, 29. https://doi.org/10.1016/j.proeng.2012.01.155

Gjems, L. (2013). Teaching in ECE: Promoting children's language learning and cooperation on knowledge construction in everyday conversations in kindergarten. Teaching and Teacher Education, 29(1), 39-45. https://doi.org/10.1016/j.tate.2012.08.008

Guswara, A. M. (2020). The Contribution of Google Classroom Application and Motivation to The Learning Outcomes of Web Programming. Educational Technology, 4(4), 1-9. https://doi.org/10.23887/jet.v4i4.29896

Haryono, H. E. (2020). The Influence of Cooperative Learning Model Type Group Investigation Toward Results of Learning Science Materials of Students. Jurnal Ilmiah Pendidikan Fisika, 4(1), 1. https://doi.org/10.20527/jipf.v4i1.1772

Heo, M., \& Toomey, N. (2020). Learning with multimedia: The effects of gender, type of multimedia learning resources, and spatial ability. Computers and Education, 146, 103747. https://doi.org/10.1016/j.compedu.2019.103747

Huang, F., Sánchez-Prieto, J. C., Teo, T., García-Peñalvo, F. J., Sánchez, E. M. T., \& Zhao, C. (2020). The influence of university students' learning beliefs on their intentions to use mobile technologies in learning: a study in China and Spain. Educational Technology Research and Development, 68(6), 3547-3565. https://doi.org/10.1007/s11423-020-09806-0

Hussin, A. A. (2018). Education 4.0 Made Simple: Ideas For Teaching. International Journal of Education and Literacy Studies, 6(3). https://doi.org/10.7575/aiac.ijels.v.6n.3p.92

Indrianto, N., \& Kurniawati. (2020). Developing Pop-Up Book Based Media To Improve The First Grader Students' Learning Achievement on The Theme of Natural Event of Min 4 Jember. Jurnal Pendidikan Dasar Nusantara, 5(2), 279-291. https://doi.org/10.29407/jpdn.v5i2.13836

Ismara, K. I., Suharjono, A., \& Supriadi, D. (2021). Ubiquitous learning in occupational health and safety for vocational education. International Journal of Evaluation and Research in Education, 10(1), 285-292. https://doi.org/10.11591/IJERE.V10I1.20823

Khan, F. M. A., \& Masood, M. (2015). The Effectiveness of an Interactive Multimedia Courseware with Cooperative Mastery Approach in Enhancing Higher Order Thinking Skills in Learning Cellular Respiration. Procedia - Social and Behavioral Sciences, 176, 977-984. https://doi.org/10.1016/j.sbspro.2015.01.567

Kkese, E. (2020). McGurk effect and audiovisual speech perception in students with learning disabilities exposed to online teaching during the COVID-19 pandemic. Medical Hypotheses, 144(July), 110233. https://doi.org/10.1016/j.mehy.2020.110233

Kurniasari, F. (2017). Implementasi Pendekatan Saintifik Pada Penugasan Aktivitas Di Buku 
Teks Bahasa Indonesia Kelas VII SMP Berdasarkan Kurikulum 2013. Jurnal Pendidikan Edutama, 4(1), 9-26. https://doi.org/10.30734/jpe.v4i1.44

Laksono, Y. S., Ariyanti, G., \& Santoso, F. G. I. (2016). Hubungan Minat Belajar Siswa Terhadap Prestasi Belajar Matematika Siswa Dalam Pembelajaran Kooperatif Tipe Stad Menggunakan Komik. Jurnal Edukasi Matematika Dan Sains, 1(2), 60-64. https://doi.org/10.25273/jems.v1i2.143.

Larue, G. S., \& Watling, C. N. (2021). Acceptance of visual and audio interventions for distracted pedestrians. Transportation Research Part F: Traffic Psychology and Behaviour, 76. https://doi.org/10.1016/j.trf.2020.12.001

Leona, N. L., Koert, M. J. H. van, Molen, M. W. van der, Rispens, J. E., Tijms, J., \& Snellings, P. (2021). Explaining individual differences in young English language learners' vocabulary knowledge: The role of Extramural English Exposure and motivation. System, 96. https://doi.org/10.1016/j.system.2020.102402

Liebech-Lien, B. (2021). Teacher teams - A support or a barrier to practising cooperative learning? Teaching and Teacher Education, 106. https://doi.org/10.1016/j.tate.2021.103453

Manurung, \& Panggabean. (2020). Improving Students' Thinking Ability In Physics Using Interactive Multimedia Based Problem Solving. Cakrawala Pendidikan, 39(2), 460-470. https://doi.org/10.21831/cp.v39i2.28205

Mega, Pudjawan, \& Margunayasa. (2015). Analisis sikap sosial siswa kelas V pada pembelajaran dengan kurikulum 2013. Mimbar PGSD Universitas Pendidikan Ganesha, 3(1). https://doi.org/10.23887/jjpgsd.v3i1.5631

Michelsanti, D., Tan, Z.-H., Sigurdsson, S., \& Jensen, J. (2019). Deep-learning-based audiovisual speech enhancement in presence of Lombard effect. Speech Communication, 115. https://doi.org/10.1016/j.specom.2019.10.006

Monica, S., Pribady, H., \& Sunarsih, E. (2017). Peningkatan Keterampilan Menyimak Cerita Pendek dengan Model Cooperativesomatic Auditory Visualization Intellectualy (SAVI) pada Siswa Kelas VII F SMP Negeri 3 Singkawang Tahun Pelajaran 2015/2016. JP-BSI (Jurnal Pendidikan Bahasa Dan Sastra Indonesia), 2(1). https://doi.org/10.26737/jpbsi.v2i1.229

Montoya, D. A. B., Plascencia, M. G. L., \& L.M.Medina Herrera. (2021). The role of reality enhancing technologies in teaching and learning of mathematics. Computers \& $\begin{array}{llll}\text { Electrical } & \text { Engineering, } & & \end{array}$ https://doi.org/10.1016/j.compeleceng.2021.107287.

Muhtar, T., \& Dallyono, R. (2020). Character Education From the Perspectives of Elementary School Physical Education Teachers. Jurnal Cakrawala Pendidikan, 39(2), 395-408. https://doi.org/10.21831/cp.v39i2.30647

Nugraha, Purnamasari, I., \& Tanuatmodjo, H. (2016). Interaction Between the Type of School and Learning Outcomes in Student's Soft Skills Enhancement through Cooperative Learning Model (Quasi Experiment on Vocational Students in Bandung). Procedia - Social and Behavioral Sciences, 219. https://doi.org/10.1016/j.sbspro.2016.05.078

Nurhusain, M. (2017). Impact Analysis of Cooperative Learning Model Application Type Two Stay Two Stray (Tsts) Toward Learning Outcomes of Mathematics. JPMI (Jurnal Pendidikan Matematika Indonesia), 2(2), 46. https://doi.org/10.26737/jpmi.v2i2.220

Parker, P. C., Perry, R. P., Hamm, J. M., Chipperfield, J. G., Dryden, R. P., \& Daniels, L. M. (2021). A motivation perspective on achievement appraisals, emotions, and performance in an online learning environment. International Journal of Educational Research, 108. https://doi.org/10.1016/j.ijer.2021.101772

Pattemore, A., \& Muñoz, C. (2020). Learning L2 constructions from captioned audio-visual 
exposure: The effect of learner-related factors. System, 93. https://doi.org/10.1016/j.system.2020.102303

Polizzi, G. (2020). Digital literacy and the national curriculum for England: Learning from how the experts engage with and evaluate online content. Computers and Education, 152. https://doi.org/10.1016/j.compedu.2020.103859

Price, C. J., Thompson, E. A., \& Cheng, S. C. (2017). Scale of Body Connection: A multisample construct validation study. PLoS ONE, 12(10), 1-13. https://doi.org/10.1371/journal.pone.0184757

Purwanita, Y., Riyanto, Y., \& Suyanto, T. (2019). The Influence of Multimedia Assisted Inquiry Learning Methods on My Heroes Theme of Critical Thinking Skills and Learning Outcomes of Class IV Students ofElementary School. International Journal of Scientific and Research Publications (IJSRP), 9(7), $\quad$ p9169. https://doi.org/10.29322/ijsrp.9.07.2019.p9169

Qusyairi, L. A. H., \& Sakila, J. (2018). Pengaruh Model Cooperative Learning Tipe InsideOutside Circle (IOC) terhadap Prestasi Belajar dengan Memperhatikan Minat Belajar Matematika. Palapa: Jurnal Studi Keislaman Dan Ilmu Pendidikan, 6(1), 34-49. https://doi.org/10.36088/palapa.v6i1.57

Rabgay, T. (2018). The effect of using cooperative learning method on tenth grade students' learning achievement and attitude towards biology. International Journal of Instruction, 11(2), 265-280. https://doi.org/10.12973/iji.2018.11218a

Rahmat, A., \& Akbar, M. (2019). A Comparative Analysis of English Learning Motivation between the Rural and Urban Students. Metathesis: Journal of English Language, Literature, and Teaching, 3(2), 158. https://doi.org/10.31002/metathesis.v3i2.1740

Ran, W., Yamamoto, M., \& Xu, S. (2016). Media multitasking during political news consumption: A relationship with factual and subjective political knowledge. Computers in Human Behavior, 56. https://doi.org/10.1016/j.chb.2015.12.015

Rubini, B., Permanasari, A., \& Yuningsih, W. (2018). Learning Multimedia Based on Science Literacy on the Lightning Theme. Jurnal Penelitian Dan Pembelajaran IPA, 4(2), 89-104. https://doi.org/10.30870/jppi.v4i2.3926

Ruengtam, P. (2013). Modeling of Cooperative/Collaborative Learning Technique: A Case Study of Interior Architectural Program. Procedia - Social and Behavioral Sciences, 105. https://doi.org/10.1016/j.sbspro.2013.11.038

Saito, K., Dewaele, J.-M., Abe, M., \& In'nami, Y. (2018). Motivation, Emotion, Learning Experience, and Second Language Comprehensibility Development in Classroom Settings: A Cross-Sectional and Longitudinal Study. Language Learning, 68(3), 709743. https://doi.org/10.1111/lang.12297

Selvianiresa, D., \& Prabawanto, S. (2017). Contextual Teaching and Learning Approach of Mathematics in Primary Schools. Journal of Physics: Conference Series, 895(1). https://doi.org/10.1088/1742-6596/895/1/012171

Setiawan, I. M. D., \& Ari Oka, I. D. G. (2020). The Use of Audio-Visual Assisted Google Classroom for Mathematics Course. Journal of Education Technology, 4(3), 244. https://doi.org/10.23887/jet.v4i3.28529

Stone, R., Cooper, S., \& Cant, R. (2013). The Value of Peer Learning in Undergraduate Nursing Education: A Systematic Review. ISRN Nursing, 2013(i), 1-10. https://doi.org/10.1155/2013/930901

Sumantri, M. S., \& Whardani, P. A. (2017). Relationship between Motivation to Achieve and Professional Competence in the Performance of Elementary School Teachers. International Education Studies, 10(7), 118. https://doi.org/10.5539/ies.v10n7p118

Sutrisno, Zar'in, F., \& Salehcah, S. (2021). Local Content Curriculum Model for Early Childhood Scientific Learning. Jurnal Pendidikan Usia Dini, 15(1). 
https://doi.org/10.21009/JPUD.151.05

Thoyyibah, N., Hartono, R., \& Bharati, D. A. L. (2019). The Implementation of Character Education in the English Teaching Learning Using 2013 Curriculum. English Education Journal, 9(2), 254-266. https://doi.org/10.15294/eej.v9i2.30058

Veselova, I., Khimich, G., \& Terentieva, E. (2021). The role of foreign language internships in cultural enrichment and increasing motivation for Russian students to learn Spanish. Heliyon, 7(9). https://doi.org/10.1016/j.heliyon.2021.e08006

Virgiana, A., \& Wasitohadi. (2016). Efektivitas Model Problem Based Learning Berbantuan Media Audio Visual Ditinjau Dari Hasil Belajar IPA Siswa Kelas 5 SDN 1 Gadu Sambong - Blora Semester 2 Tahun 2014/2015. Scholaria: Jurnal Pendidikan Dan Kebudayaan, 6(2), 100-118. https://doi.org/10.24246/j.scholaria.2016.v6.i2.p100-118

Wang, Z., Wang, L., \& Huang, H. (2020). Joint low rank embedded multiple features learning for audio-visual emotion recognition. Neurocomputing, 338. https://doi.org/10.1016/j.neucom.2020.01.017

Wardani, D. T. (2015). Pengaruh Pembelajaran Kooperatif Tipe Stad (Student Teams Achievement Divisions) Dan Jigsaw Terhadap Prestasi Belajar Ekonomi Ditinjau Dari Motivasi Belajar Siswa Tahun Ajaran 2014/2015. EQUILIBRIUM: Jurnal Ilmiah Ekonomi Dan Pembelajarannya, 3(2), 105-112. https://doi.org/10.25273/equilibrium.v3i2.657

Widiatmika, D. G., Sujana, I. W., \& Ganing, N. N. (2017). Pengaruh Model Discovery Learning Berbantuan Media Audio Visual Terhadap Kompetensi. MIMBAR PGSD Undiksha, 5(2), 1-8. https://doi.org/10.23887/jjpgsd.v5i2.11786

Widowati, H. (2011). Penerapan Pembelajaran Kooperatif Model Examples Non Examples Dan Stad Pada Mata Kuliah Struktur Hewan Program Studi Pendidikan Biologi. Bioedukasi: Jurnal Pendidikan Biologi Fkip Um Metro, 2(1). https://doi.org/10.24127/bioedukasi.v2i1.202

Wulandari, I. G. A. A. (2020). Implementation of the 2013 Curriculum Based on a Scientific Approach (Case Study at SD Cluster II Kintamani). International Journal of Elementary Education, 4(3), 422-430. https://doi.org/10.23887/ijee.v4i3.28172

$\mathrm{Xu}, \mathrm{X} .$, \& Wu, H. (2021). Audio-visual interactions enhance soundscape perception in China's protected areas. Urban Forestry \& Urban Greening, 61. https://doi.org/10.1016/j.ufug.2021.127090

Zahro, Degeng, \& Mudiono, A. (2018). Pengaruh model pembelajaran student team achievement devision (STAD) dan mind mapping terhadap hasil belajar siswa kelas IV sekolah dasar. Educandum: Jurnal Pendidikan Dasar Dan Pembelajaran, 8(2). https://doi.org/10.25273/pe.v8i2.3021 